\title{
Grandeur in this view of life
}

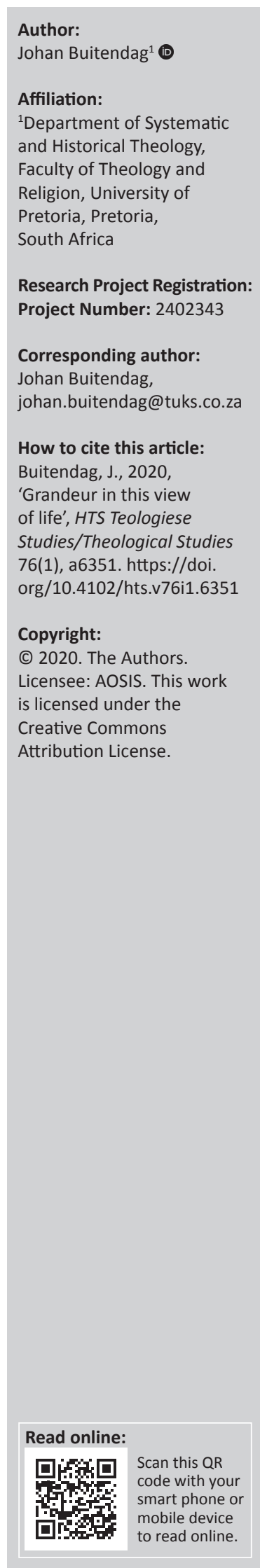

I have chosen, as the title of my editorial for this special collection on 'Theology and Nature' of the HTS Teologiese Studies/Theological Studies, the introductory words of the very last sentence of Charles Darwin's famous 'On the Origin of Species' (Darwin [1859] 1999):

There is grandeur in this view of life, with its several powers, having been originally breathed [by the Creator] into a few forms or into one; and that, whilst this planet has gone cycling on according to the fixed law of gravity, from so simple a beginning endless forms most beautiful and most wonderful have been, and are being, evolved. (p. 400)

Theology is in my view 'a scholarly endeavour of believers in the public sphere to inquire into a multi-dimensional reality in a manner that matters' (Buitendag 2014:6). It was therefore with acclamation when I read many years ago General Jan Smuts' 'Holism and Evolution' and his extraordinary admiration and awe he had for the above-mentioned paragraph of Darwin (Smuts, [1926] 1987:186). Smuts concluded his seminal work, with a similar appealing last paragraph, augmented evolutionary biology of Darwin:

The holistic nisus which rises like a living fountain from the very depths of the universe is the guarantee that failure does not await us, that the ideals of Well-being, of Truth, Beauty and Goodness are firmly grounded in the nature of things, and will not eventually be endangered or lost. Wholeness, healing, holiness - all expressions and ideas springing from the same root in language as in experience - lie on the rugged upward path of the universe, and are secure of attainment - in part here and now, and eventually more fully and truly. The rise and self-perfection of wholes in the Whole is the slow but unerring process and goal of this Holistic universe. (p. 345)

Darwin omitted the words 'by the Creator' in the later editions of this book, and Smuts never used the word either, but surely both of them implicated God irrefutably as epitomised by the upper case in Smuts' citation.

The Earth Charter ${ }^{1}$ was formally launched in a special ceremony on 29 June 2000 at The Peace Palace in The Hague, the Netherlands, and is now exactly 20 years old and highly influential in all circles engaging in Earth-keeping and astro-theology. ${ }^{2}$ Despite that the word 'God' is not used here either, the principle is present, especially in the well-formulated and holistic preamble?

We stand at a critical moment in Earth's history, a time when humanity must choose its future. As the world becomes increasingly interdependent and fragile, the future at once holds great peril and great promise. To move forward we must recognize that in the midst of a magnificent diversity of cultures and life forms we are one human family and one Earth community with a common destiny. We must join together to bring forth a sustainable global society founded on respect for nature, universal human rights, economic justice, and a culture of peace. Towards this end, it is imperative that we, the peoples of Earth, declare our responsibility to one another, to the greater community of life, and to future generations. (n.p.)

The four pillars of The Earth Charter are displayed in Figure 1.

I am greatly honoured by the invitation of the Editor-in-Chief of the HTS Theological Studies to conduct this special edition and have embraced the opportunity enthusiastically as ecotheology has been my major field of research since my doctoral studies in the early eighties of the previous century.

\footnotetext{
1.The Earth Charter was created by the independent Earth Charter Commission, which was convened as a follow-up to the 1992 Earth Summit in order to produce a global consensus statement of values and principles for a sustainable future. The document was developed over nearly a decade through an extensive process of international consultation, to which over 5000 people contributed. The Charter has been formally endorsed by thousands of organisations, including UNESCO and the IUCN (World Conservation Union). For more information, please visit www. EarthCharter.org.

2.'Astro-theology is a dialogical field of scholarly study at the intersection of religious reflection and natural science. The astro-theologian asks: what are the implications of space exploration and the possibility of discovery of extraterrestrial life, either microbial life within our solar system or intelligent civilisations on exoplanets? At minimum, astro-theologians draw out the religious, social and ethical implications of astrobiology. At maximum, Muslim, Christian and other religious thinkers engage in doctrinal construction' (Peters 2019:n.p.).
} 


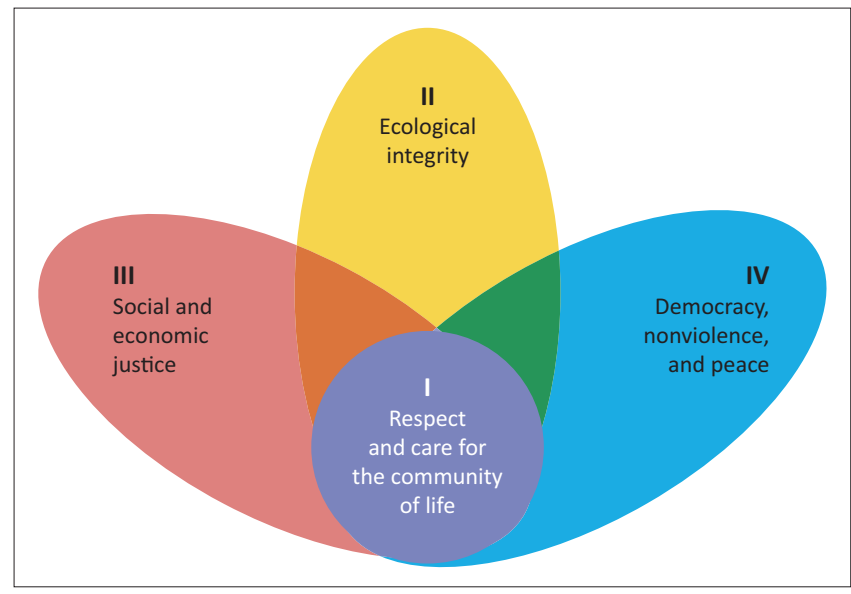

Source: Earth Charter International (ECI), n.d., The Earth Charter, viewed 02 October 2020 from https://earthcharter.org/about-us/earth-charter-international/

FIGURE 1: The Four Pillars of The Earth Charter.

Several scholars have been approached to contribute to this special edition, far less than could have been invited. Of course, not all could accept the invitation at the time and not all could make the deadline, but I am excited about the array of contributions. Some contributors were my former PhD students; others are my colleagues and the rest my coresearchers in the research field of 'Understanding Reality' at the Faculty of Theology and Religion of the University of Pretoria.

With this special collection of 'Theology and Nature', the HTS Teologiese Studies/Theological Studies sets the pace amongst South African journals of this kind. Acknowledgement should be given to the multi-religious approach - especially Christianity and Islam - and more importantly, the Islamic perspectives were presented by Muslim scholars themselves (Is this a first for this journal?). Acknowledgement should also be given to the two articles opening up and shifting horizons to outer space, seeing the whole cosmos (whether universe or multiverse) as a matter of no small degree for theological discernment, contemplation and engagement.

In my cited definition of how I see theology, I have concluded with the words, 'in a matter that matters'. This is why we need an ethics of planetary sustainability and something like an 18th Sustainable Development Goal (perhaps 'Space Environment') of the United Nations. ${ }^{4}$

It is my sincere hope that this special edition will continue in 2021 as there are still some articles in expectation and more importantly, much to explore.

Johan Buitendag

Pretoria

\section{Acknowledgements Competing interests}

The author declares that he has no financial or personal relationships that may have inappropriately influenced him in writing this editorial.

\section{Disclaimer}

The views and opinions expressed in this article are those of the author and do not necessarily reflect the official policy or position of any affiliated agency of the author.

\section{References}

Buitendag, J., 2014, 'Between the Scylla and the Charybdis: Theological education in the 21st century in Africa', HTS Teologiese Studies/Theological Studies 70(1), 5. https://doi.org/10.4102/hts.v70i1.2855

Darwin, C., [1859] 1999, On the Origin of Species, Bantam Books, New York, NY.

Earth Charter International (ECI), n.d., The Earth Charter, viewed 02 October 2020, from https://earthcharter.org/about-us/earth-charter-international/.

Peters, T., 2019, 'Astrotheology', Scholarly Community Encyclopedia 2020. Outstanding Contributor Awards, viewed 02 October 2020, from https://encyclopedia.pub/244. Smuts, J., [1926] 1987, Holism and Evolution, N \& S House, Cape Town.

4.See https://www.un.org/sustainabledevelopment/. 